\title{
Students' Translation Use in English Foreign Language (EFL) Learning
}

\author{
Masitorwani Siregar \\ State University of Medan, Indonesia
}

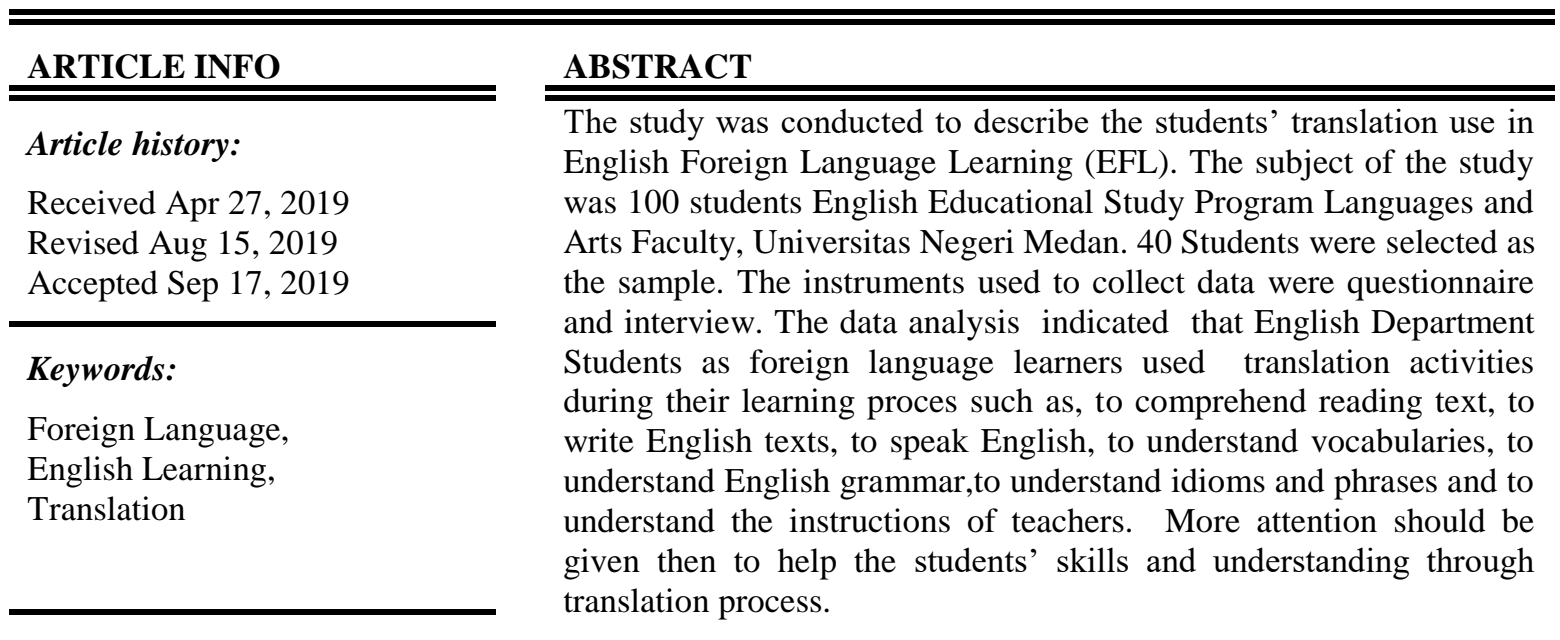

Clonflict of Interest:

None

Funding:

None

Corresponding Author: Masitowarni Siregar, English Education Study Program, State University of Medan, Indonesia, E-mail: siregarmasitowarni@yahoo.com

Copyright (C) Association of Language Teachers in Southeast Asia. All rights reserved

\section{Introduction}

Language skills (listening, speaking, reading, and writing) are the important skills which should be mastered by the learners in studying foreign language. English, a foreign language, needs more techniques in learning language itself. Exposing the language gradually is the main difficulty in learning foreign language. It is caused by the human brain which is able to assimilate the rhythms, new sounds, and tones. Therefore, the rhythms, new sounds, and tones can be suitable with a recently way in alluding ideas and objects. In addition, an increasing of the foreign language material is needed to be exposed. It is difficult to find the material. Books or audio resources will be used to begin the process preferred toward learning language technique. From those sources in getting some materials, the learner needs to know the meaning of the materials that use English. In getting the meaning the learners will try to find it out by doing translation.

Translation is an activity neglected as the major influence toward Grammar-Translation Method and translation application in the classroom teaching foreign language the classroom. Based on the historical analysis of the translation evolution over the years helps the learners to identify and to understand the key elements as strong stages of the concept discredit (Carolina, 2015).

Therefore, translation can become English Language Teaching (ELT) technique in the classroom. Since relating to daily communication, translation makes the learners using translation. The function of learners' translation use in the classroom are peering, decoding signs and noticing in the environment, the learners also 
translate the instructions and letters in communicating with friends and relations, etc. Furthermore, a unified of goods and persons, and multilingual will be increased. Therefore, translation must be often implemented on daily communication.

However, there are many language theoreticians and teachers that reject translation in teaching foreign language even though translation is a foreign language related skill. Cook (2010) stated that in twentieth century, translation was the high-profile language teaching in improving language skills. Therefore, the end of that century, translation was not discussed in the university level that discussed academic literature in assisting of a new language learning.

Translation was used to interpret the information received from source language into target language. Translation will translate the words or sentences meaning semantically and pragmatically. Translation can reach its ultimate goal when it is conducted on a professional level. In addition, translation can be also as language learning facilitation and a process to gain the new language that can help foreign language learners in comprehending the language. Furthermore, translation has the various methods in teaching language provided for the learners having different social background as translation is an appropriate technique in helping the student to understand a foreign language and expressing the ideas into target language. Even though, some teachers believe that use the native speaker of foreign language in teaching that language is a serious barrier in teaching foreign language effectively (Numan, 2014).

Translation is one of techniques in learning language, translation can develop the students' language skills and teach the source and target language relating to communicative language functions, sentential information structure, discourse values, and semantic relationship. Not only that, but translation is also a cognitive activity which can assist the students to learn new expressions and phrases of a target language. Then the learners can use translation to communicate with others. Translation is also a students' problemsolving to develop their capabilities in processing and analyzing data of a foreign language. Therefore, translation is the appropriate technique in language learning. Since the translation also has a propensity toward foreign language teaching and learning.

English and Literature Department students must master some English materials in order to make the students are able to master all English skills such as comprehending a reading text; writing English text; speaking English; understanding vocabularies; understanding English grammar; understanding idioms and phrases; and understand teachers' instruction. Translation is an appropriate technique in mastering English skills as a foreign language.

Therefore, the study aimed to describe students' translation use in EFL Learning. By finding out how the students use translation to comprehend a foreign learning, it will be known that the translation is an appropriate technique learning English as a foreign language.

\section{Literature Review}

\subsection{Translation Use in Language Learning}

Translation was used to facilitate the information received from source language into target language. Translation can be used in all the situations and places, include in the classroom. Furthermore, translation as a communicative activity can be used to express various types of texts, lists, styles, contexts, etc (Duff, 1989). Based on the explanation above, students use translation in order to understand teachers' instruction and also interactions occurred between them. Therefore, translation is one of important English skills that should be mastered by the learners in developing and improving communicative skill (Ross, 2000). Cook (2010) stated that translation skill is an important component of bilingual communication.

The use of translation is able to increase students' awareness related to the languages involved in communicating. In translation, the students will comprehend the translation problematic nature and focus on cultural gaps, linguistics, and extra linguistic of source and target languages (Guerra, 2012). In translation assignment, it is required the students' consideration toward how to achieve equality semantically, functionally, and pragmatically. Since the students will try to find out the adequacy and suitability of the communicative objectives.

Some researches have done in the previous year, Carreres (2006) was considered as a pioneer of Translation analysis in the Language Teaching students' opinions. Carreres conducted a research by giving a questionnaire for 31 seconds and third years modern language students at Cambridge University. Based on the research, it was known that translation was needed at the level of modern languages, and the most of correspondences considered that translation use is a very useful language learning tool in a foreign language learning for example, vocabularies learning. 15 students also considered translation is an effective method for learning a foreign language, although the other correspondences did not find fun or satisfying translation. Furthermore, Liao (2006) did the research about a translation role in Taiwanese English Foreign Language students related to students' main learning strategy and students' translation use. Taiwanese English Foreign 
Language students considered that translation use in intermediate to high level was an appropriate learning strategy. The students also said that translation has a good role in learning English as a foreign language. However, the students have a tendency to consider translation as inappropriate strategy. Since, those students used less translation, compared to the students who were lack of ability in foreign language.

\section{Method}

The study used a descriptive qualitative method in analyzing the problem of the study. A descriptive qualitative method was used to describe the research subject or object related to data found in the study field. Issac et al (1981) stated that in portraying the population and evidence found factually, systematically, and accurately, the study conducted a descriptive qualitative method.problem formulation, data collection, data analyzing and concluding were conducted as some stages in doing the study to gain the result of the study . The data of the study were collected the results of the questionnaire. There were several steps in collecting data which were making, sharing, and collecting a questionnaire. Firstly, the questionnaires were made to obtain the data of the study. Secondly, the questionnaires were shared to the subject of the study namely 100 English educational program students. Thirdly, the questionnaires were collected.

Descriptive qualitative analysis was conducted to analyze the data of the study. There were several steps in analyzing the data of the study such as, reading the questionnaires which were collected from 100 English educational program students; counting the results of the questionnaires; identifying the data obtained; and explaining the result of data analysis.

\section{Result and Discussion}

The research data were taken based on the questionnaire given to 100 students of English Educational Study Program students, languages and art faculty, Universitas Negeri Medan. The questionnaires contained 24 statements. The first until second statements are about the translation functions in learning English such as, mastering four language skills ; memorizing the vocabularies; understanding the grammar rules, idioms, and phrase. Then, the eleventh until the seventeenth statements contained about the function of Bahasa Indonesia use in translation; and the eighteenth until twentieth contained about how important Bahasa Indonesia use in a translation technique. The questionnaire result is shown in Table 1.

Table 1. The Questionnaire Result

\begin{tabular}{|c|c|c|c|c|c|}
\hline \multirow{2}{*}{ Statement } & \multicolumn{5}{|c|}{ Percentage } \\
\cline { 2 - 6 } & 5 & 4 & 3 & 2 & 1 \\
\hline 1 & $51.6 \%$ & $41.9 \%$ & $6.4 \%$ & - & - \\
\hline 2 & $32.2 \%$ & $51.6 \%$ & $16.1 \%$ & - & - \\
\hline 3 & $41.9 \%$ & $45.1 \%$ & $12.9 \%$ & - & - \\
\hline 4 & $38.7 \%$ & $45.2 \%$ & $16.1 \%$ & - & - \\
\hline 5 & $41.9 \%$ & $41.9 \%$ & $16.1 \%$ & - & - \\
\hline 6 & $16.1 \%$ & $58.1 \%$ & $19.4 \%$ & $6.4 \%$ & - \\
\hline 7 & $29 \%$ & $41.9 \%$ & $25.8 \%$ & $3.2 \%$ & - \\
\hline 8 & $9.7 \%$ & $32.2 \%$ & $6.4 \%$ & $19.4 \%$ & $32.2 \%$ \\
\hline 9 & $19.4 \%$ & $45.2 \%$ & $22.6 \%$ & $12.9 \%$ & - \\
\hline 10 & $12.9 \%$ & $61.3 \%$ & $22.6 \%$ & $3.2 \%$ & - \\
\hline 11 & $29 \%$ & $35.5 \%$ & $22.6 \%$ & $12.9 \%$ & - \\
\hline 12 & $35.5 \%$ & $29 \%$ & $29 \%$ & $6.4 \%$ & - \\
\hline 13 & $19.4 \%$ & $25.8 \%$ & $35.5 \%$ & $16.1 \%$ & $3.2 \%$ \\
\hline 14 & $16.1 \%$ & $38.7 \%$ & $25.8 \%$ & $3.2 \%$ & $16.1 \%$ \\
\hline 15 & $25.8 \%$ & $25.8 \%$ & $38.7 \%$ & $9.7 \%$ & - \\
\hline 16 & $12.9 \%$ & $29 \%$ & $45.2 \%$ & $12.9 \%$ & - \\
\hline 17 & $16.1 \%$ & $25.8 \%$ & $38.7 \%$ & $19.4 \%$ & - \\
\hline 18 & $9.7 \%$ & $41.9 \%$ & $38.7 \%$ & $3.2 \%$ & $6.4 \%$ \\
\hline 19 & $9.7 \%$ & $29 \%$ & $41.9 \%$ & $9.7 \%$ & $9.7 \%$ \\
\hline 20 & $41.9 \%$ & $38.7 \%$ & $12.9 \%$ & $6.4 \%$ & - \\
\hline 21 & $19.4 \%$ & $32.2 \%$ & $32.2 \%$ & $6.4 \%$ & $9.3 \%$ \\
\hline 22 & $3.2 \%$ & $25.8 \%$ & $38.7 \%$ & $19.4 \%$ & $12.9 \%$ \\
\hline 23 & $35.5 \%$ & $22.6 \%$ & $29 \%$ & $9.7 \%$ & $3.2 \%$ \\
\hline 24 & $16.1 \%$ & $51.6 \%$ & $29 \%$ & $3.2 \%$ & - \\
\hline & & & & & \\
\hline
\end{tabular}


After analyzing data found, it was known that the highest percentage which is $51,6 \%$ showed that English Department Students as foreign language learners used translation activities during their learning process including to comprehend reading text, to write English texts, to speak English, to understand vocabularies, to understand English grammar,to understand idioms and phrases and to understand teachers' instruction. Furthermore, there were half of students stated that Bahasa Indonesia use as target language in translation technique is an appropriate technique to comprehend English as s foreign language. It means that translation was very important in teaching and learning English process. In addition, Bahasa Indonesia was important to be used in translation to learn English. Then, the students also considered to use Indonesian language as a target language in implementing translation as an English learning technique.

\section{Conclusion}

The data analysis result related to the translation function which is in translation the students will comprehend the translation problematic nature and focus on cultural gaps, linguistics, and extra linguistic of source and target languages (Guerra, 2012). Not only that, but translation use was also able to improve the students' awareness toward correspondence between the languages involved in communicating.

Therefore, translation is an appropriate technique in English language teaching in the classroom. It makes that the students used translation as a technique to comprehend a foreign language. Peering, decoding signs and noticing in the environment, the students as the foreign language learners are done in translation technique. Not only that, but translation is also used to translate the instructions and letters in communicating with friends and relations, etc.

\section{References}

Carolina. (2015). The Role of Translation in Foreign Language Learning and Teaching. Universidad De Jaén: Centro de Estudios de Postgrado.

Carreres, Á. (2006). Strange Bedfellows: Translation and Language Teaching. The Teaching of Translation into L2 in Modern Languages Degrees: Uses and Limitations, In SixthSymposium on Translation, Terminology and Interpretation in Cuba and Canada. December2006,La Havana: Canadian Translators, Terminologists and Interpreters Council (online): 1- 21.

Cook, G. (2010). Translation in Language Teaching: an Argument for Reassessment. Oxford: Oxford University Press.

Duff, A. (1989). Translation. Oxford: Oxford University Press.

Fernández Guerra, A. (2012). The issue of (un)translatability revisited: theoretical and practical perspectives. Forum. International Journal of Translation Studies 10: 35-60.

Isaac, S. and Michael, W.B. (1981). Handbook in Research andEvaluation. California: EDIT Publisher.

Liao, P. (2006). EFL Learners' Beliefs about and Strategy Use of Translation in English Learning.RELC. Regional Language Centre Journal 37(2): 191-215.

Numan. (2014). Strategic Use of Translation in Learning English as a Foreign Language (EFL) among Bahrain University Students. Accessed https://journals.sagepub.com/doi/full/10.2466/10.03.IT.3.4On November, $06^{\text {th }} 2019$

Numan. (2017). What are the main difficulties in learning a new language not a programming language. Accessed from https://www.quora.com/What-are-the-main-difficulties-in-learning-a-new-languagenot-a-programming-language\# on November, $06^{\text {th }} 2019$.

Ross, N. J. (2000). Interference and Intervention: Using Translation in the EFL Classroom. ModernEnglish Teacher 9(3): 61-66. 